\title{
Impulsivity in obese women
}

Citation for published version (APA):

Nederkoorn, C., Smulders, F. T. Y., Havermans, R. C., Roefs, A. J., \& Jansen, A. T. M. (2006). Impulsivity in obese women. Appetite, 47, 253-256. https://doi.org/10.1016/j.appet.2006.05.008

Document status and date:

Published: 01/01/2006

DOI:

10.1016/j.appet.2006.05.008

Document Version:

Publisher's PDF, also known as Version of record

\section{Document license:}

Taverne

\section{Please check the document version of this publication:}

- A submitted manuscript is the version of the article upon submission and before peer-review. There can be important differences between the submitted version and the official published version of record.

People interested in the research are advised to contact the author for the final version of the publication, or visit the DOI to the publisher's website.

- The final author version and the galley proof are versions of the publication after peer review.

- The final published version features the final layout of the paper including the volume, issue and page numbers.

Link to publication

\footnotetext{
General rights rights.

- You may freely distribute the URL identifying the publication in the public portal. please follow below link for the End User Agreement:

www.umlib.nl/taverne-license

Take down policy

If you believe that this document breaches copyright please contact us at:

repository@maastrichtuniversity.nl

providing details and we will investigate your claim.
}

Copyright and moral rights for the publications made accessible in the public portal are retained by the authors and/or other copyright owners and it is a condition of accessing publications that users recognise and abide by the legal requirements associated with these

- Users may download and print one copy of any publication from the public portal for the purpose of private study or research.

- You may not further distribute the material or use it for any profit-making activity or commercial gain

If the publication is distributed under the terms of Article $25 \mathrm{fa}$ of the Dutch Copyright Act, indicated by the "Taverne" license above, 


\author{
Chantal Nederkoorn*, Fren T.Y. Smulders, Remco C. Havermans, Anne Roefs, Anita Jansen \\ Department of Experimental Psychology, Maastricht University, The Netherlands
}

Received 31 October 2005; received in revised form 28 April 2006; accepted 2 May 2006

\begin{abstract}
In our obesogenic environment, self-control might be necessary in order to prevent overeating. Impulsivity is supposed to make it more difficult to resist the temptation to eat too much and can thereby contribute to overweight. In the present study, the hypotheses is tested that obese individuals are more impulsive. Thirty-one obese and 28 lean women, sampled from the normal population, are tested on a behavioural measure and three self-report measures of impulsivity. The obese women appeared more impulsive on the last part of the behavioural task, but not on the self-report measures. Implications of the results are discussed.
\end{abstract}

(C) 2006 Elsevier Ltd. All rights reserved.

Keywords: Obesity; Impulsivity; Response inhibition; Delay discounting; Sensation seeking

\section{Introduction}

The incidence of obesity has increased dramatically in the past few decades. The consequences are enormous, both for obese individuals and for society. The availability of high caloric, tasty food items plays an important role; the temptation is omnipresent. However, although the relation between the increase in availability of tasty food and the increase in obesity is obvious, it cannot explain obesity on the individual level. After all, not everyone experiences difficulties in limiting one's food intake, while enduring the same food overexposure. What then makes this difference between normal weight and obese persons?

There is some evidence that obese people are more prone to give in to temptations and are less effective in inhibiting their impulses. Self-reports show that obese people are more impulsive than lean people and show co-morbidity with other impulsive behaviours, like substance abuse (Chalmers, Bowyer, \& Olenick, 1990; Rydén et al., 2003; Williamson, Kelley, Davis, Ruggiero, \& Blouin, 1985). In addition, it has been found that obese children are less able to delay gratification and more often choose a direct reward over a larger delayed reward, which is an index of

\footnotetext{
*Corresponding author.

E-mail address: c.nederkoorn@psychology.unimaas.nl (C. Nederkoorn).
}

diminished self-control (Bonato \& Boland, 1983), although inconsistent results are found (Bourget \& White, 1984). Recent research has also shown that obese children in a treatment programme are less effective in response inhibition in a stop signal task and are more sensitive to reward in a gamble task than lean children (Nederkoorn, Braet, Van Eijs, Tanghe, \& Jansen, in press). Obese adults showed a preference for high immediate gain, but larger future losses in a gamble task, instead of lower immediate gain, but smaller future loss, indicating poor and impulsive decision making (Davis, Levitan, Muglia, Bewell, \& Kennedy, 2004). Moreover, Holtkamp et al. (2004) found that children with attention deficit/hyperactivity disorder (ADHD), who are impulsive by definition, had a higher BMI and incidence of obesity, compared to reference values. Recently, co-morbidity between obesity and ADHD was reported in children (Agranat-Meged et al., 2005). Not only do obese people in general appear more impulsive, within obese individuals high impulsivity is related to less weight loss during treatment (Jonsson, Bjorvell, Levander, \& Rossner, 1986; Nederkoorn, Braet, et al., in press; Nederkoorn, Jansen, Mulkens, \& Jansen, in press) and is predictive of treatment drop-out (Hjordis \& Gunnar, 1989).

In sum, there is growing evidence that obese people are impulsive in several aspects. However, the exact relation between impulsivity and obesity is still far from clear. Most 
of previous research on impulsivity and obesity relies on self-report, which is subject to demand characteristics. Behavioural research with obese adults is particularly scarce. Moreover, impulsivity is a very broad concept, incorporating many different aspects, and is defined and measured in many different ways. Correlations between these different measures of impulsivity are low (Barkley, 1991). So if it is concluded that obese people are more impulsive, what does this exactly mean?

In the present study, several measures of impulsivity will be used. One behavioural measure will be used: response inhibition as measured with the stop signal task, and three self-report measures, namely delay discounting, the trait impulsiveness of the Eysenck Personality Profiler (EPP) and sensation seeking.

\section{Method}

Participants were called for by advertisements in a Dutch national woman's magazine and a local newspaper, in which obese and lean women, younger than 50 years, were asked to participate. Thirty-one obese women (mean BMI $39.0, \mathrm{SD}=5.3$ ) and 28 normal weight women (mean BMI $22.5, \mathrm{SD}=2.2$ ) participated. Mean age of the normal weight group was $41.8(\mathrm{SD}=7.4)$, mean age of the obese group was $40.9(\mathrm{SD}=6.6$; not significant $t(56)=0.5)$.

The stop signal task (Logan, Schachar, \& Tannock, 1997) was used to measure response inhibition. Response inhibition, measured with this task, has shown to be related to impulsivity (Logan et al., 1997) and to discriminate between obese and lean children (Nederkoorn et al., in press) and between restrained and unrestrained eaters (Nederkoorn, Van Eijs, \& Jansen, 2004). In the stop signal task (for more detail, see Logan et al., 1997), people must respond as fast as possible on a choice reaction time (RT) task, unless a stop signal is presented in which case their response must be inhibited ( $25 \%$ of the trials). The delay of the stop signal was adjusted dynamically dependent on the responses of the subject. The two variables measured in this task are RT and mean stop delay. The stop signal reaction time (SSRT) was calculated by subtracting the stop delay from the RT. Higher stop signal RTs means less inhibitory control. The participants completed four blocks of 128 trials successively.

Delay discounting was used to measure the preference for direct smaller rewards over delayed larger rewards. While for everyone a reward discounts in value if the delay gets longer, this effect is stronger for impulsive people and substance-dependent individuals, and they will choose more often the immediate reward (Madden, Petry, Badger, \& Bickel, 1997). In the delay discount procedure used (for more details, see Madden et al., 1997), participants had to choose between two hypothetical monetary amounts: a lower amount now (ranging from 990 to $100 €$ ) or $1000 €$ later, and seven delayed times are used, ranging from 1 week to 25 years. The point in which someone switches from the delayed reward to the immediate reward (or visa versa) is noted. With the formula $V=A /(1+k D)$, in which $V$ is the turning point, $A$ is the delayed reward of 1000 , and $D$ is the delay in days, $k$ can be calculated for each of the seven delays used. The $k$ value determines the speed of discounting and higher $k$ values are indicative of higher impulsivity.

The trait impulsiveness of the EPP (Eysenck \& Wilson, 1991) was used to measure a personality trait of acting on the spur of the moment, making hurried decisions and carefree, changeable and unpredictable behaviour. Restrained eaters are found to report higher impulsiveness than unrestrained eaters (Nederkoorn et al., 2004). On a related measure, obese people indicated higher incidence of impulsiveness compared to a control group (Rydén et al., 2003). The questionnaire consists of 20 items, each item is scored on a three-point scale, from 2 (agree) to 0 (not agree). Higher scores indicate higher impulsiveness.

The Dutch sensation seeking scale (SBL, Feij, Van Zuilen, \& Gazendam, 1982), based on the SBL of Zuckerman (1994) measures the seeking of varied novel, and intense situations and experiences, and the willingness to take risks for the sake of such experiences. The scale is related to substance abuse (Jones \& Lejuez, 2005) and impulsive pathology (Zuckerman, 1994). In Rydén et al. (2003), no difference between obese people and a reference group was found on aversion to boredom, a component of sensation seeking. The scale comprises four subscales: thrill and adventure seeking (TAS), experience seeking (ES), disinhibition (DIS) and boredom susceptibility (BS). Only the last two subscales were administered. The DIS subscale exists of 12 items and the BS subscale of 13 items. Each item is scored from 5 (totally agree) to 1 (totally disagree). Higher scores mean higher sensation seeking.

Participants received the Dutch SBL and the trait impulsiveness of the EPP by mail. The other two measures of impulsivity were administered in our lab. Body weight and length were measured and the participants received travel expenses and a small fee.

\section{Results}

The first hypothesis was that obese women show longer stop times (SSRTs), indicating a deficit in response inhibition. Overall, no significant difference was found $(F(1,56)=1.8, p=0.18)$. The group $\times$ block interaction was however significant $(3,55)=3.6, p<.05)$, see Fig. 1 . As can be inferred from the figure, both groups clearly showed a practice effect: in block 1 the SSRTs were longer than in the other blocks. While at first there was no difference between the groups, at the end of the task, the obese group started to have more difficulties with response inhibition than the control group. $T$ tests of the blocks separately showed that the groups differed marginally at block 3 $(t(56)=1.7, p<.1$ and significant at block $4(t(56)=2.2$, $p<.05)$. No differences between groups were found on their RTs $(F(1,56)=.6, p=.45)$ and the group*block interaction was not significant $(F(3,55)=.2, p=.9)$, meaning 


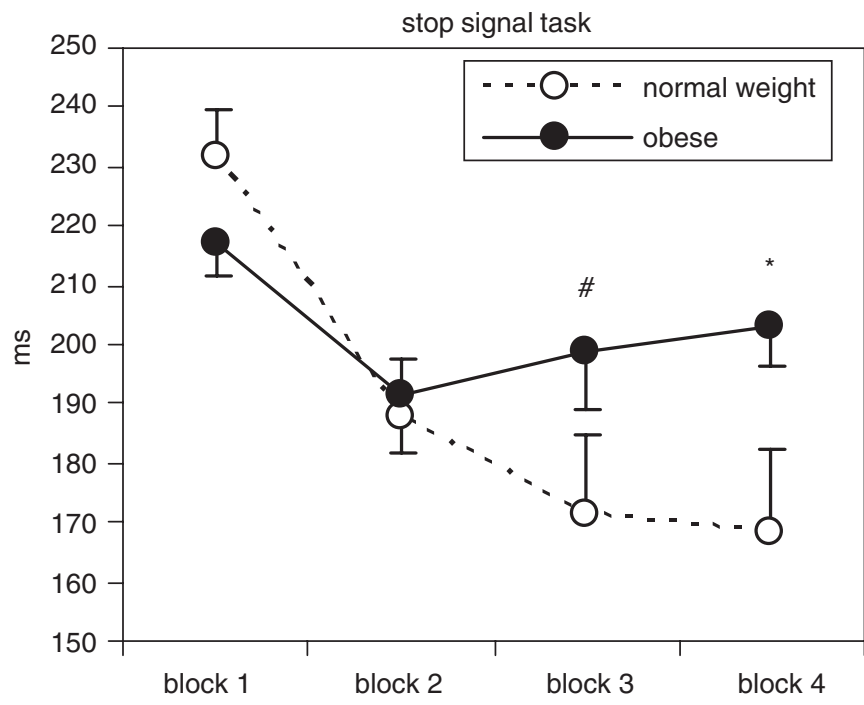

Fig. 1. Stop signal reaction times (SSRTs) of obese and normal weight women. ${ }^{\#} p<.1,{ }^{*} p<.05$.

that the obese women had no difficulties in responding per se.

No differences between groups were found on delay discounting $(t(56)=1, p=.3)$, the trait impulsiveness of EPP $(t(56)=1.4, p=.16)$ and the SBLs (DIS: $t(56)=1$, $p=.3$, BS: $t(56)=1.5, p=.14)$.

\section{Discussion}

Obese women were expected to appear more impulsive on several measures. Indeed, the present results showed that the obese women were more impulsive on the stop signal task than the normal weight women: obese women inhibited their responses less adequately during the stop signal task in the last blocks, while they had no difficulties in responding per se. This is line with previous research, in which obese children and restrained eaters are found to show less adequate response inhibition, compared to their control groups (Nederkoorn et al., in press, 2004).

On the self-report measures, no group difference was found. This is not in concordance with previous research, in which obese participants did report higher impulsivity (e.g. Rydén et al., 2003). However, the power in this study is limited, and it is possible that with more participants, group differences would be found on the self-report measures. It is also possible that in this study, in which the experimental group was explicitly selected on their weight status, evaluation apprehension was especially high, which may have influenced the self-report. The different outcomes for behavioural and self-report measures is in concordance with a study of Wonderlich, Connolly and Stice (2004), who found that objective measures of impulsivity like delinquency or substance abuse did predict onset of eating disordered behaviour but self-report measures of impulsivity did not. This suggests that behavioural measures might be more adequate to measure impulsivity, in obesity and eating disorders, than selfreport. Self-report measures can be biased by demand characteristics and lack of self-insight, and therefore their validity can be questioned.

The obese women in this study did show less effective response inhibition, at the end of the task. Speculating about the nature of this relationship, it can be hypothesized that that less adequate behavioural inhibition underlies overeating, especially in the omnipresent temptation of palatable food. Frequent overeating in turn, can lead to overweight and obesity. This is in line with research on other consumptive behaviour. For example, impulsive people are found to ingest more alcohol (Loxton \& Dawe, 2001) and caffeine (Jones \& Lejuez, 2005). It is possible that the various consumptive behaviours are related and that the same fundamental lack of control underlies excessive use or intake, although the outlet differs.

The relation between response inhibition and obesity can perhaps also explain the disappointing results of weight control treatments, based on self-regulation of energy intake (Lowe, 2003). It seems that self-control should be improved in order to find enduring effects. However, this is difficult to learn. Most research on improving inhibitory control stems from treatment of children with ADHD. An overview of empirically based treatments (Barkley, 2004) shows that contingency management strategies are most effective, besides medication, although the effects usually do not generalize across different situations and do not last after treatment. These kinds of strategies are also used in treatment of obesity. For example, Epstein, McKenzie, Valoski, Klein, and Wing (1994) found that contingent reinforcement in a family-based weigh control programme for overweight children and their parents was more effective than a noncontingent reinforcement at 6 months and 1 year, but these effects were not maintained at 2 years.

There is also some research at the effect of methylphenidate, a frequently used and very effective medicine for children with ADHD, on weight loss. Treatment with methylphenidate reduces BMI in children with ADHD, especially in children with a higher BMI (Schertz, Adesman, Alfieri, \& Bienowski, 1996). Leddy et al. (2004) found that methylphenidate reduced energy intake in obese men during a palatable meal. They suggested that the mechanism might be altered hunger, satiety, macronutrient preference or altered rewarding value of food. It is, however, also possible that the methylphenidate increased inhibitory control in the obese men, making it easier for them to stop eating and finish the palatable meal. Methylphenidate may possibly help (morbid) obese people to control food intake and lose weight subsequently.

The main conclusion of this paper is that the obese women showed deficits in response inhibition on a behavioural measure, while they did not appear impulsive on self-report measures. These findings are partly consistent with the hypothesis that impulsivity might play a role in the cause of obesity. Further research is needed to confirm the relation between impulsivity and obesity. 
Moreover, the possibility that helping obese people to control their impulses might help them to lose weight seems worth investigating.

\section{References}

Agranat-Meged, A. N., Deitcher, C., Goldzweig, G., Leibson, L., Stein, M., \& Galili-Weisstub, E. (2005). Childhood obesity and attention deficit/hyperactivity disorder: A newly described comorbidity in obese hospitalized children. International Journal of Eating Disorders, 37, 357-359.

Barkley, R. A. (1991). The ecological validity of laboratory and analogue assessment methods of ADHD symptoms. Journal of Abnormal Child Psychology, 19, 149-178.

Barkley, R. A. (2004). Adolescents with attention-deficit/hyperactivity disorder: An overview of emperically based treatments. Journal of Psychiatric Practice, 10, 39-56.

Bonato, D. P., \& Boland, F. J. (1983). Delay of gratification in obese children. Addictive Behaviors, 8, 71-74.

Bourget, V., \& White, D. R. (1984). Performance of overweight and normal-weight girls on delay of gratification tasks. International Journal of Eating Disorders, 3(3), 63-71.

Chalmers, D. K., Bowyer, C. A., \& Olenick, N. L. (1990). Problem drinking and obesity: A comparison in personality patterns and lifestyle. International Journal of Addiction, 25, 803-817.

Davis, C., Levitan, R. D., Muglia, P., Bewell, C., \& Kennedy, J. L. (2004). Decision-making deficits and overeating: A risk model for obesity. Obesity Research, 12, 929-935.

Epstein, L. H., McKenzie, S. J., Valoski, A., Klein, K. R., \& Wing, R. R. (1994). Effects of mastery criteria and contingent reinforcement for family-based child weight control. Addictive Behaviors, 19, 135-145.

Eysenck, H. J., \& Wilson, G. D. (1991). The Eysenck Personality Profiler. Worthing, UK: Psi-Press.

Feij, J. A., Van Zuilen, R. W., \& Gazendam, A. (1982). The development of a Dutch sensation seeking questionnaire. Gedrag: Tijdschrift voor Psychologie, 10, 364-383.

Hjordis, B., \& Gunnar, E. (1989). Characteristics of drop-outs from a long-term behavioral treatment program for obesity. International Journal of Eating Disorders, 8, 363-368.

Holtkamp, K., Konrad, K., Muller, B., Heussen, N., Herpertz, S., Herpertz-Dahlmann, B., et al. (2004). Overweight and obesity in children with Attention-deficit/hyperactivity disorder. International Journal of Obesity, 28, 685-689.

Jones, H. A., \& Lejuez, C. W. (2005). Personality correlates of caffeine dependence: The role of sensation seeking, impulsivity, and risk taking. Experimental and Clinical Psychopharmacology, 3, 259-266.
Jonsson, B., Bjorvell, H., Levander, S., \& Rossner, S. (1986). Personality traits predicting weight loss outcome in obese patients. Acta Psyciatrica Scandinavia, 74, 384-387.

Leddy, J. J., Epstein, L. H., Jaroni, J. L., Roemmich, J. N., Paluch, R. A., Goldfield, G. S., et al. (2004). Influence of methylphenidate on eating in obese men. Obesity Research, 12, 224-232.

Logan, G. D., Schachar, R. J., \& Tannock, R. (1997). Impulsivity and inhibitory control. Psychological Science, 8, 60-64.

Lowe, M. R. (2003). Self-regulation of energy intake in the prevention and treatment of obesity: Is it feasible? Obesity Research, 11(Suppl), $44 \mathrm{~S}-59 \mathrm{~S}$.

Loxton, N. J., \& Dawe, S. (2001). Alcohol abuse and dysfunctional eating in adolescent girls: The influence of individual differences in sensitivity to reward and punishment. International Journal of Eating Disorders, 29, 455-462.

Madden, G. J., Petry, N. M., Badger, G. J., \& Bickel, W. K. (1997). Impulsive and self-control choices in opioid-dependent patients and non-drug-using control patients: Drug and monetary rewards. Experimental and Clinical Psychopharmacology, 5(3), 256-262.

Nederkoorn, C., Braet, C., Van Eijs, Y., Tanghe, A., \& Jansen, A. Why obese children can not resist food: The role of impulsivity. Eating Behaviors, in press.

Nederkoorn, C., Jansen, E., Mulkens, S., \& Jansen, A. Impulsivity predicts treatment outcome in obese children. Behaviour Research and Therapy, in press, doi:10.1016/j.brat.2006.05.009.

Nederkoorn, C., Van Eijs, Y., \& Jansen, A. (2004). Restrained eaters act on impulse. Personality and Individual Differences, 37, 1651-1658.

Rydén, A., Sullivan, M., Torgerson, J. S., Karlsson, J., Lindroos, A. K., \& Taft, C. (2003). Severe obesity and personality: A comparative controlled study of personality traits. International Journal of Obesity, 27, 1534-1540.

Schertz, M., Adesman, A. R., Alfieri, N. E., \& Bienowski, R. S. (1996). Predictors of weight loss in children with attention deifict hyperactivity disorder treated with stimulant medication. Pediatrics, 98, $763-769$.

Williamson, D. A., Kelley, M. L., Davis, C. J., Ruggiero, L., \& Blouin, D. C. (1985). Psychopathology of eating disorders: A controlled comparison of bulimics, obese and normal subjects. Journal of Consulting and Clinical Psychology, 53, 161-166.

Wonderlich, S. A., Connolly, K. M., \& Stice, E. (2004). Impulsivity as a risk factor for eating disorder behavior: Assessment implications with adolescents. International Journal of Eating Disorders, 36, $172-182$.

Zuckerman, M. (1994). Behavioral expressions and biosocial bases of sensation seeking. Cambridge: Cambridge University Press. 